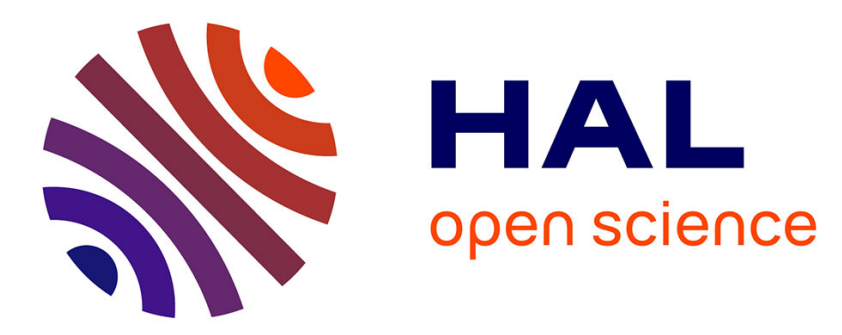

\title{
Spatio-Temporal LSTM Forecasting of Ozone Secondary Events
}

Luiz Angelo Steffenel, Gustavo Rasera, Nelson Bègue, Damaris Kirsch, Hassan

Bencherif

\section{- To cite this version:}

Luiz Angelo Steffenel, Gustavo Rasera, Nelson Bègue, Damaris Kirsch, Hassan Bencherif. SpatioTemporal LSTM Forecasting of Ozone Secondary Events. European Geosciences Union General Assembly (EGU), 2019, Vienna, Austria. 21, Geophysical Research Abstracts. 10.1002/essoar.10500904.1. hal-02120012

\section{HAL Id: hal-02120012 \\ https://hal.univ-reims.fr/hal-02120012}

Submitted on 4 May 2019

HAL is a multi-disciplinary open access archive for the deposit and dissemination of scientific research documents, whether they are published or not. The documents may come from teaching and research institutions in France or abroad, or from public or private research centers.
L'archive ouverte pluridisciplinaire HAL, est destinée au dépôt et à la diffusion de documents scientifiques de niveau recherche, publiés ou non, émanant des établissements d'enseignement et de recherche français ou étrangers, des laboratoires publics ou privés. 


\title{
Spatio-Temporal LSTM Forecasting of Ozone Secondary Events
}

\author{
Luiz Angelo Steffenel (1), Gustavo Rasera (1), Nelson Begue (3), Damaris Kirsch Pinheiro (2), and Hassan \\ Bencherif (3) \\ (1) Université de Reims Champagne-Ardenne, CReSTIC Laboratory EA 3804, Reims, France \\ (luiz-angelo.steffenel@univ-reims.fr, grasera13@gmail.com), (2) Universidade Federal de Santa Maria, Santa Maria RS, \\ Brazil (damaris@ufsm.br), (3) Université de La Réunion, LACy Laboratory UMR 8105, Reunion Island, France \\ (hassan.bencherif@univ-reunion.fr, nelson.begue@univ-reunion.fr)
}

Given the dynamics of the atmosphere, the ozone hole is accompanied by episodes of exchange between the polar vortex and the mid-latitudes and the tropics (Bencherif et al., 2007). During these events, the polar vortex is deformed and ozone-poor polar air-masses move towards the tropics. We call these episodes of isentropic exchanges "Ozone Secondary Effects" (OSE), and several events have been observed during the last decade. For example, an event observed on October 14, 2012 reached the south of Brazil (Peres et al., 2017), causing $13.7 \%$ reduction in the total columns of ozone. Recently, Bresciani et al. (2018) reported on a major OSE event (23\% reduction in TCO) and its influence in southern Brazil and Uruguay that occurred in October 2016. Such OSE episodes may last up to 3 weeks, causing a potential increasing in the UV radiation levels leading to public health issues as well as impacts on the fauna and flora, with notable risks for the biodiversity and the agriculture.

In the present study, we investigate the use of Long Short-Term Memory recurrent neural networks to forecast OSE events, more specifically the Causal LSTM model proposed by Wang et al. (2018), which has been successfully applied to the analysis of video images. In our study, however, the input data is composed by historical data for the total column of ozone (TCO), obtained by satellites. We aim at using the resulting forecasts to detect, monitor and classify OSE events by isentropic levels, latitudinal bands and geographical areas. We believe that these results can be integrated into a weather forecast workflow to improve the accuracy of existing models.

Further experiments include the conjoint analysis of other atmospheric markers such as the potential vorticity (PV). Together with auxiliary parameters such as cloud fraction, aerosol optical depth, nebulosity and altitude, these forecasts could be used to produce realistic UV-Index estimations.

Bencherif H., El Amraoui L. , Semane N. , Massart S. , Charyulu D.V., Hauchecorne A. and Peuch V.-H.: Examination of the 2002 major warming in the southern hemisphere using ground-based and Odin/SMR assimilated data: stratospheric ozone distributions and tropic/mid-latitude exchange, Can. J. Phys., 85, 1287-1300, 2007 Bresciani C., Bittencourt G. D., Bageston J. V., Pinheiro D. K., Schuch N. J., Bencherif H., Leme N. P., and Peres L. V.: Report of a large depletion in the ozone layer over southern Brazil and Uruguay by using multi-instrumental data, Ann. Geophys., 36, 405-413

Peres L.V., Bencherif H., Mbatha N., Schuch A.P., Toihir A. M., Bègue N., Portafaix T., Anabor V., Pinheiro D. K, Leme N. M.P. Bageston J. V., Schuch N. J.: Measurements of the total ozone column using a Brewer spectrophotometer and TOMS and OMI satellite instruments over the Southern Space Observatory in Brazil, Ann. Geophys., 35, 25-37, 2017.

Wang Y., Gao Z., Long M., Wang J. and Yu P.S. : PredRNN++: Towards A Resolution of the Deep-in-Time Dilemma in Spatiotemporal Predictive Learning . 35th Intl Conf on Machine Learning, PMLR 80:5123-5132, 2018. 